Acta Technologica Agriculturae 3

Nitra, Slovaca Universitas Agriculturae Nitriae, 2015, pp. 57-63

\title{
RESULTS FROM RECENT TRAFFIC SYSTEMS RESEARCH AND THE IMPLICATIONS FOR FUTURE WORK
}

\section{Richard GODWIN*1, Paula MISIEWICZ1', David WHITE', Emily SMITH'1 , Tim CHAMEN², Jana GALAMBOŠOVÁ ${ }^{3}$, Ron STOBART ${ }^{4}$}

'Harper Adams University, Newport, Shropshire, United Kingdom

${ }^{2}$ CTF Europe, Maulden, Bedfordshire, United Kingdom

${ }^{3}$ Slovak University of Agriculture in Nitra, Slovak Republic

${ }^{4}$ NIAB TAG, Morley, Norfolk, United Kingdom

\begin{abstract}
This paper reviews the results of recent traffic systems research and concludes that the evidence shows that with sufficient ingenuity by farmers and their equipment suppliers to match operating and wheel track widths, the traffic management systems that reduce soil compaction should improve crop yield, reduce energy consumption and improve infiltration rates (which will reduce runoff, erosion and flooding). These together will improve agronomic, economic and environmental sustainability of agriculture. Low ground pressure alternatives may well be the option that best suits some farming enterprises and should not be discounted as viable traffic management methods. The paper also considers the implications for further work to improve the robustness of the experimental data.
\end{abstract}

Keywords: controlled traffic farming; tillage; cereals; yield; soil management

In the 1970's Soane and his fellow workers, in Scotland, showed that approximately $95 \%$ of a field growing spring barley was covered by wheel marks during crop establishment operations. Recently Kroulik et al. (2009) using global positioning system-tracking devices monitored the field operations for cereal production. Their data revealed that resulting from the Random Traffic Farming (RTF) practices showed that $85 \%, 65 \%$ and $42 \%$ of the field was randomly tracked by at least one wheel pass for conventional tillage, minimum tillage and direct drilling/no-till systems respectively. Further studies at Harper Adams University (Kroulik et al., 2012) showed that $65 \%$ of the field was wheel tracked in a single harvest of grass silage due to both the baling and forage wagon operations and $84 \%$ of a field was wheel tracked during potato planting operations. This then suggests that much could be gained from controlled traffic farming practices (CTF) (Tullberg et al., 2007) where field operations are focused on predetermined wheel ways and equipment widths and wheel track spacing are matched.

The potential advantages through avoiding compaction from CTF are:

1. Improved crop yields, similar to those shown in Figure 1 by Negi et al. (1981) and the main focus of this paper.

2. Reduced tillage and crop establishment energy (Chamen et al., 1992a \& b) as illustrated in Table 1.

3. Improved soil conditions and infiltration of rainfall/ irrigation water (Chyba, 2012) as shown in Figure 2. By proportioning these results to the number of traffic passes these give an average infiltration rate of approximately $18.5 \mathrm{~mm} / \mathrm{h}$ for a controlled traffic system compared to approximately $5 \mathrm{~mm} / \mathrm{h}$ for random traffic farming systems. This near four-fold increase in infiltration is in agreement with the field data collected by Chamen (2011).

These are achievable providing that the mechanisation systems can be organised to enable the correct implement/ vehicle operating and track gauges to be matched. An alternative to CTF is to consider the use of lower tyre (ground) pressure systems (LGP), which has become more practical for higher power tractors with the introduction of ultra-flex tyres (Michelin). These can operate at inflation pressures of 0.7 bar where the tractor equipped with conventional tyres would have tyres inflated to 1.2 bar and 1.5 bar for the front and rear tyres respectively, thus reducing the level of soil compaction (Soehne, 1958).

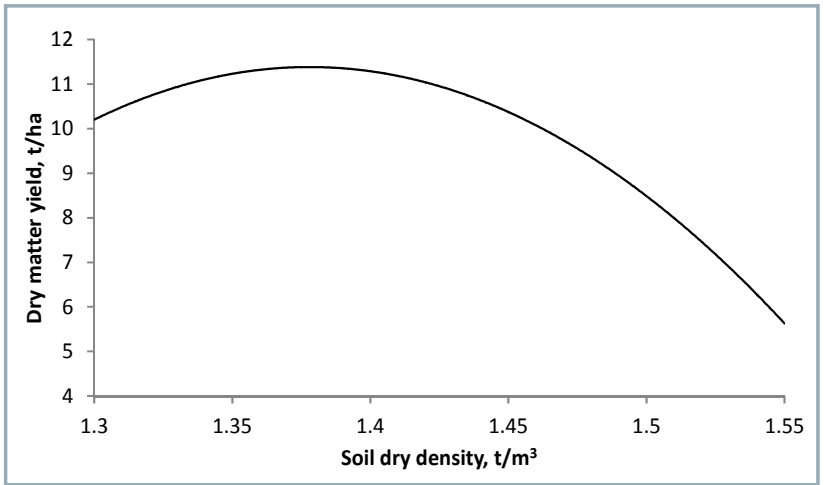

Figure 1 Effect of soil density on maize dry matter yield Source: Negi et al., 1981 
Table 1 Traffic control effects on tillage energy

\begin{tabular}{|c|c|c|c|}
\hline \multicolumn{2}{|l|}{ Traffic } & \multicolumn{2}{|c|}{ No Traffic } \\
\hline \multicolumn{4}{|c|}{ Primary tillage (MJ/ha) } \\
\hline Shallow plough & 107 & Shallow plough & 47 \\
\hline \multicolumn{4}{|c|}{ Secondary tillage (MJ/ha) } \\
\hline Spring tine & 57 & & \\
\hline Power harrow & 108 & & \\
\hline Harrow & 29 & Harrow & 25 \\
\hline Drill & 31 & Drill & 27 \\
\hline Roll & 30 & Roll & 27 \\
\hline Total secondary & 255 & Total secondary & 79 \\
\hline
\end{tabular}

Source: Chamen et al., 1992a \& b

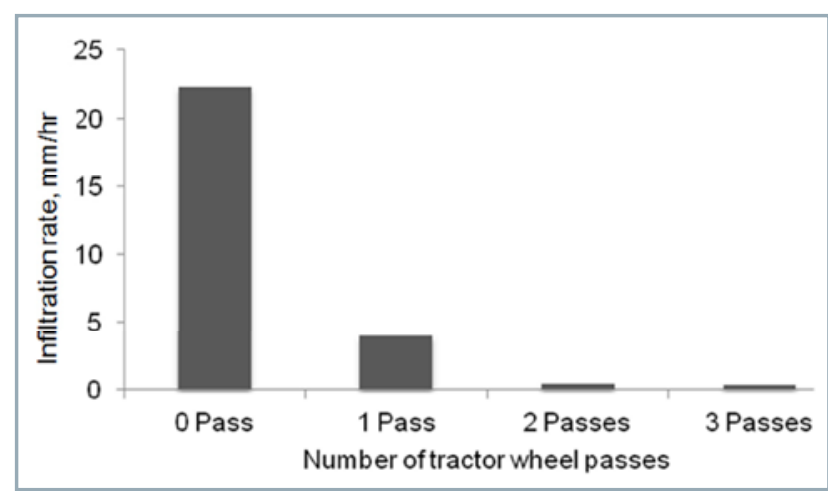

Figure 2 Effect of the number of tractor wheel passes on infiltration rate in a sandy clay loam Source: Chyba, 2012

\section{Crop Yield Response to Controlled Traffic}

Chamen (2011) reported that yield improvements of $7 \%$ to $35 \%$ have been recorded for a range of crops in a number of different international studies, see Figure 3 . These data are very promising, however, not all of the results were from replicated experiments and soil compaction, if present, was not reported as being alleviated by soil loosening prior to the initiation of the work. In many cases the work was conducted in either adjacent or split fields with one in random traffic and the other in controlled traffic management.

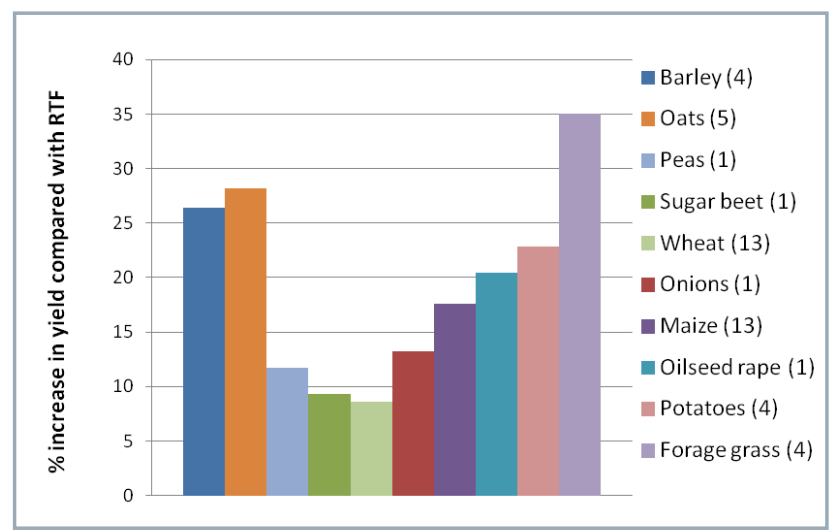

Figure 3 The average yield benefit from controlled traffic farming compared to random traffic farming. Numbers in parenthesis indicate the number of studies reported

Source: Chamen, 2011
In order to overcome these issues randomised replicated studies were initiated by Cranfield University and The Arable Group (TAG) at Morley, Norfolk, UK in 2007 and at Colworth and Chicksands, Bedfordshire, UK in 2009; the Slovak University of Agriculture, Nitra, Slovakia in 2010 and Harper Adams University, Newport, Shropshire, UK in 2011.

\section{Cranfield University - TAG Studies}

The replicated field plot studies by Cranfield University in conjunction with TAG at Morley showed improvements in the yield of winter wheat as given in Table 2 for two depths of tillage (shallow 5-15 cm and deep 15-25 cm). These showed a $15.5 \%$ and $16.4 \%$ improvement in yield where all traffic was removed from the field plots in the crop establishment operation for the two depths of tillage respectively and a $12 \%$ and $5.5 \%$ improvement where the machinery operations were confined to a rubber tracked vehicle.

Table 2 Winter wheat yields from the Cranfield University - TAG study at Morley at two tillage depths

\begin{tabular}{|l||c|c|}
\hline \multirow{2}{*}{ Treatment } & \multicolumn{2}{c|}{ Wheat yield (t/ha) } \\
\cline { 2 - 3 } & Shallow tillage & Deep tillage \\
\hline \hline $\begin{array}{l}\text { Random traffic (conventional } \\
\text { tyres at recommended } \\
\text { inflation pressure) }\end{array}$ & 10.84 & 10.79 \\
\hline $\begin{array}{l}\text { Zero traffic + rubber tracked } \\
\text { vehicle }\end{array}$ & 12.14 & 11.38 \\
\hline Zero traffic & 12.52 & 12.56 \\
\hline \multicolumn{2}{|l}{$c v=7.8 \%, p<0.07, I s d=1.52 \mathrm{t} / \mathrm{ha}$} \\
\end{tabular}

For operational reasons this experiment could not be continued and Chamen (2011) established two, more detailed experiments with controlled traffic compared to 11 and 8 further traffic/tillage systems at the Colworth and Chicksands sites respectively. Those treatments showing the greatest difference at the Colworth site are given in Figure 4. This shows that whilst the CTF yield is not uniquely larger than the other traffic management systems, it is significantly different from 9 other systems, with the exception of the wheeled cultivation tractor with and without the following drill tractor as shown.

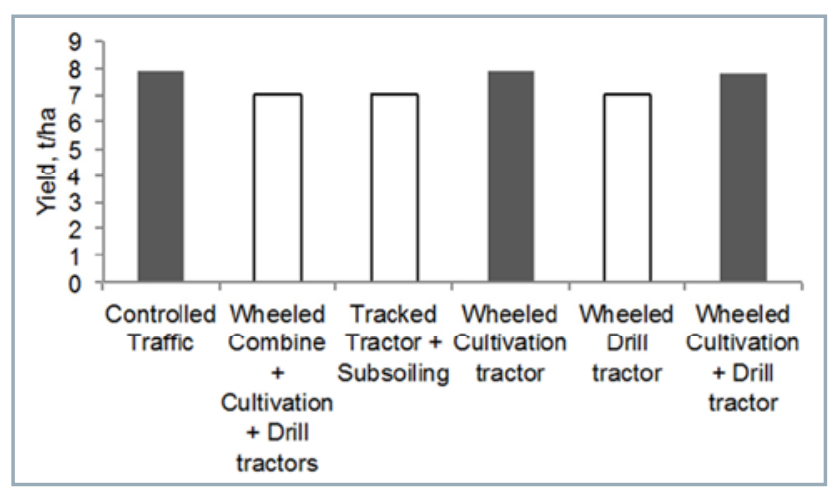

Figure 4 Winter wheat yield from different treatments at Colworth, 2010

White and grey columns are significantly different at $p<0.05 ;$ isd $=0.62 \mathrm{t} / \mathrm{ha}$

Source: Chamen, 2011 
The overall winter wheat yield at the Chicksands site was low, with a mean yield of approximately $4.5 \mathrm{t} / \mathrm{ha}$ with no significant differences, even at 10\% level ( $c v$ of $15 \%$ and an estimated $/ s d$ of $1.00 \mathrm{t} / \mathrm{ha}$ ). The probable cause of this variability was reported as being due to differences in water availability across the sandy loam site. Those treatments that had not been trafficked since deep loosening (including those which had received treatment compaction) yielded marginally higher than all the remaining treatments.

\section{Slovak University of Agriculture Studies}

In the Slovak experiment (Galambošová et al., 2010 and 2014) a 16 ha field was managed using $6 \mathrm{~m}$ wide CTF systems and three $33 \mathrm{~m}$ wide compacted (RTF) zones crossed the direction of the CTF traffic as shown in Figure 5. This enabled crop yields to be harvested from 4 traffic conditions at 18 sampling points, namely:

- 9 points with CTF with no traffic and CTF with an intermediate wheel pass;

- 9 points with RTF with 1 wheel pass per year and RTF multiple wheel passes.

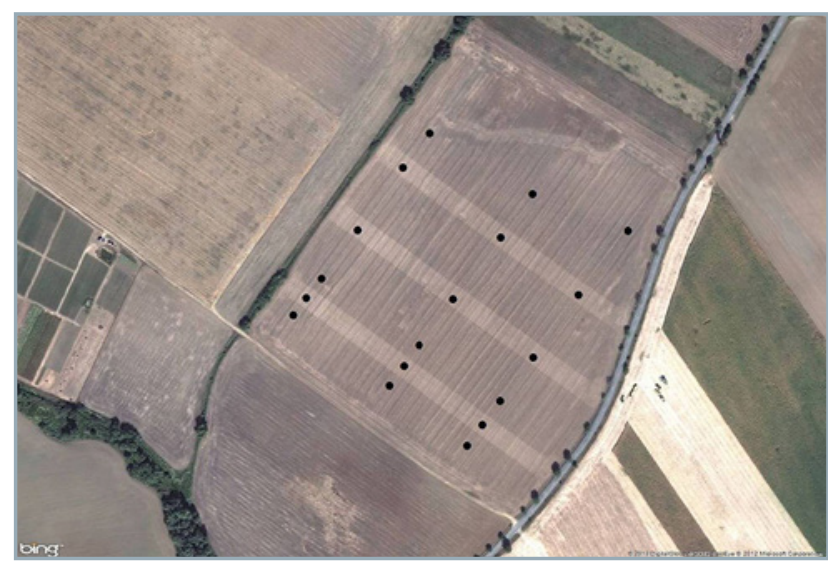

Figure 5 Field layout and sampling locations in Nitra Source: Galambošová et al., 2010 and 2014
The yield for the three cropping seasons shows that the CTF No Traffic treatment had advantages over the RTF Multiple Passes treatment for all crops/seasons. These differences are very attractive to practical farmers. With the spring barley showing the greatest difference (50\%) which is statistically significant at $5 \%$ probability; followed by maize (32.5\%) which is statistically significant at $15 \%$ probability and winter wheat (10\%) statistically significant at $10 \%$ probability.

\section{Harper Adams University Studies}

In order to determine if the tillage system had an effect upon the choice of traffic systems, Harper Adams University established a long-term experiment in 2011. A sandy loam field was chosen for this study, which was initially drained at $13 \mathrm{~m}$ spacing and the field subsoiled to a depth of approximately $0.5 \mathrm{~m}$ to remove deep compaction. In order to ensure the minimum heterogeneity for the experimental area, the field was scanned using electromagnetic resonance techniques, to determine differences in soil texture, see Figure 6 (left). This alongside some conventional soil mapping indicated that the zone marked " $\mathrm{A}$ " was the most homogenous (Kristof et al., 2012). Following this a winter wheat crop was established in forty $80 \mathrm{~m}$ long by $4 \mathrm{~m}$ wide plots with $0.6 \mathrm{~m}$ wide wheel tracks at $2.1 \mathrm{~m}$ centres. The selected traffic and tillage treatments were not applied in the first season, the site was allowed to "recover" from the pre-treatments and the spatial uniformity of the proposed plot-treatment zones determined (Smith et al., 2013). The uniformity of the crop during the growing season was determined from the normalised difference vegetation index (NDVI) data shown in Figure 6 (right) which again shows zone " $A$ " the most uniform. Figure 7 illustrates the typical crop conditions of the field. Each of the plots were harvested using a $4 \mathrm{~m}$ wide combine harvester equipped with a yield monitoring device and the total yield/plot weighed; the coefficient of variation of the wheat yield of the proposed experimental site was $6 \%$. From the 40 plots

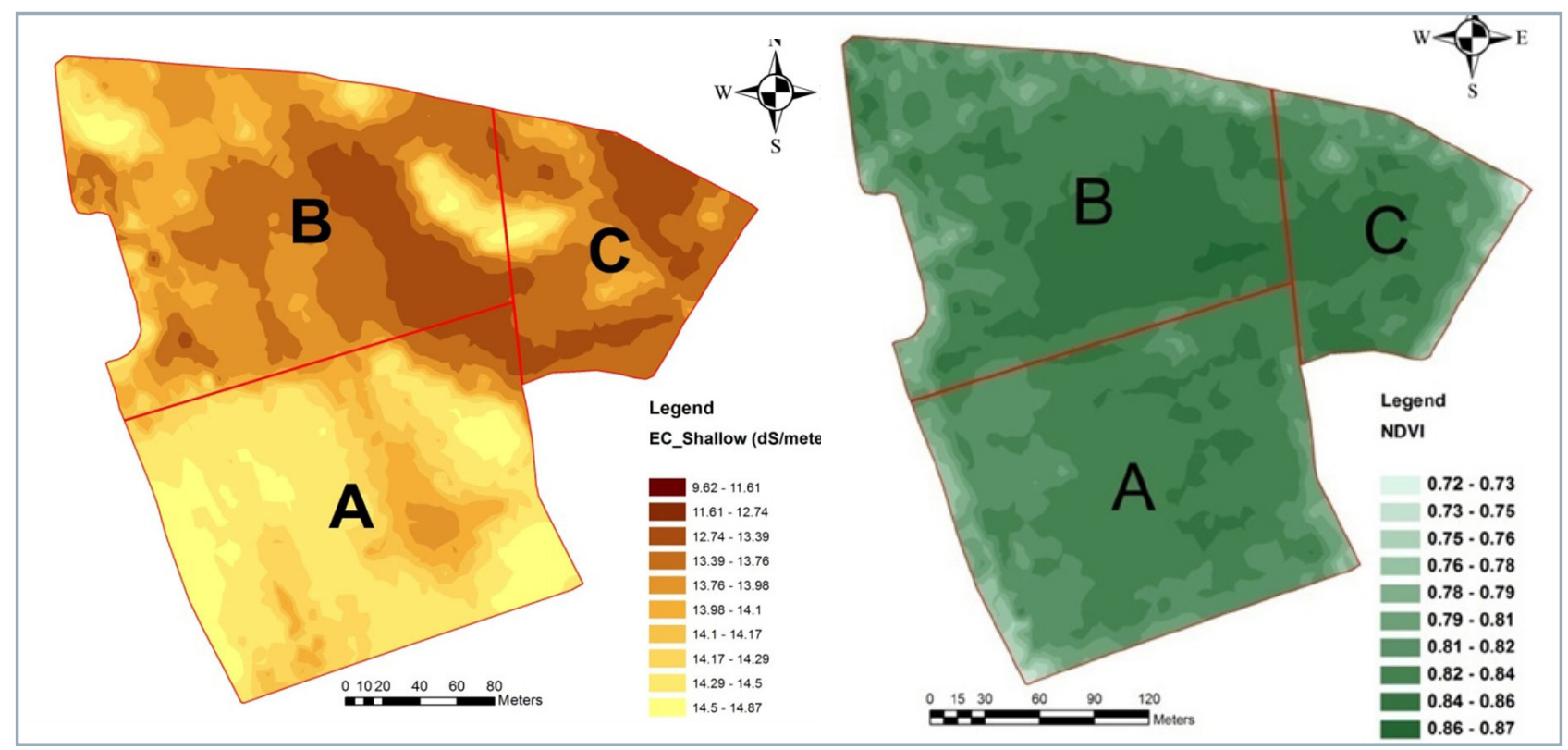

Figure 6 Soil uniformity from electro-magnetic induction field scanning (left) and crop uniformity from field scanning using Crop Circle 


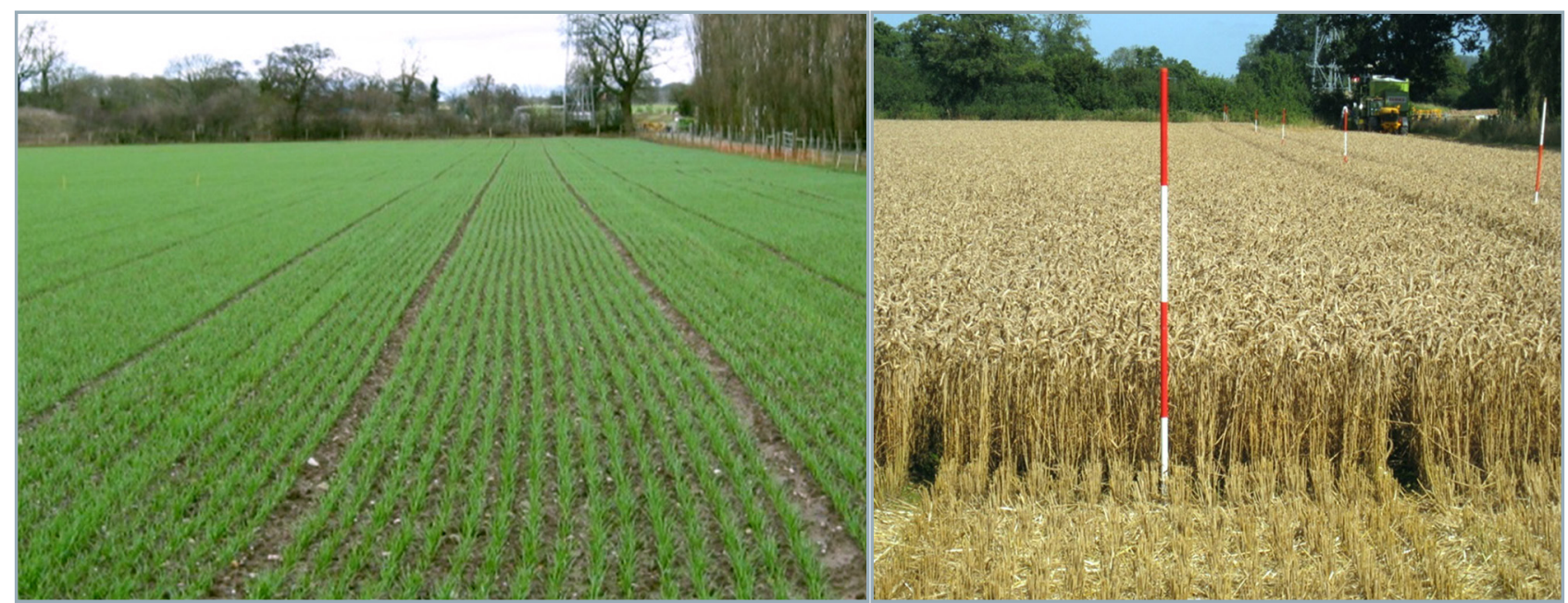

Figure 7 Crop uniformity after establishment (left) and prior to harvest (right)

36 were chosen for treatments in 4 randomised blocks to determine the relative effects of three traffic management systems, namely:

1. Random traffic farming (RTF) with 1.2 bar and 1.5 bar inflation pressure in the front and rear tyres respectively of a $12 \mathrm{t}$ front wheel assist tractor.

2. Lower ground pressure farming (LGP) with 0.7 bar inflation pressure in both the front and rear tractor tyres of a $12 \mathrm{t}$ front wheel assist tractor.

3. Controlled traffic farming system with a $16 \mathrm{t}$ rubber tracked track-laying tractor undertaking the cultivation and drilling operations (CTF).

These traffic effects were combined with 3 tillage treatments in a $3 \times 3$ factorial design, namely:

1. Deep tillage $(0.25 \mathrm{~m})$.

2. Shallow tillage $(0.10 \mathrm{~m})$.

3. Zero tillage.

The traffic treatments were installed in the autumn of 2012, 2013 and 2014 following the traffic intensity patterns (both area and number of passes) of the tillage system reported by Kroulik et al. (2009). Both deep and shallow tillage were conducted using a $4 \mathrm{~m}$ wide tillage implement (Vaderstad Topdown). Crop establishment was conducted in all treatments using a Vaderstad Rapid drill in 2012 and a Vaderstad Spirit drill in 2013 and 2014.

The results of this work are best summarised by the analysis undertaken by the lead author of the data given by
Smith et al. (2014) reported in Godwin (2014) and Godwin and Spoor (2015) as given below.

Crop establishment in the first year of the treatment (2012) was difficult due to the wet autumn; however, the grand mean wheat yield at $7.54 \mathrm{t} /$ ha (Table 3 ) was typical for the UK [mean 7.8 t/ha: NFU (2013)]. The major problem was the poor establishment, growth and yield in the traffic lanes of the zero tilled plots of all traffic systems, as shown in Figure 8, which reduced the overall yield. The severity of this is shown by the analysis of very small hand harvested samples from the controlled traffic system plots given in Table 4, where the yield in the traffic lanes of the zero tillage plots was only $4.33 \mathrm{t} / \mathrm{ha}$.

The data in Table 3 show that the mean controlled traffic yields were significantly $(p<0.10)$ higher $(0.5 \mathrm{t} / \mathrm{ha}$ or $7 \%$ ) than the random traffic yield, with the yield of the low ground pressure system midway between them.

Plot widths of $4 \mathrm{~m}$ were chosen for operational reasons; hence, the trafficked area of the CTF plots was high at 30\% of the total area. Many CTF farmers are attempting to reduce this to c. 15\%; e.g., 10-12 m wide controlled traffic systems with 1.8-2 $\mathrm{m}$ covered with wheel marks. The adjusted estimated yields for a $15 \%$ traffic lane area are also given in Table 3.

The CTF/shallow tillage treatment (for the 30\% traffic lane area) shows a significant $(p<0.10) 15 \%(1.1 \mathrm{t} / \mathrm{ha})$ increase in yield over RTF/deep tillage (effectively conventional farming practice), and similarly the LGP/

Table 3 Combine harvested winter wheat yield ( $\mathrm{t} / \mathrm{ha}$ ) in 2013 for a range of tillage and traffic systems

\begin{tabular}{|l|c|c|c|c|c|}
\hline & $\begin{array}{c}\text { Random } \\
\text { Traffic RTF }\end{array}$ & $\begin{array}{c}\text { Low Ground } \\
\text { Pressure LGP }\end{array}$ & $\begin{array}{c}\text { Controlled Traffic CTF } \\
\text { (30\% traffic lane area) }\end{array}$ & Mean & $\begin{array}{c}\text { Controlled Traffic CTF } \\
\text { (15\% traffic lane area) }\end{array}$ \\
\hline Deep Tillage & 7.29 & 7.71 & 7.93 & $7.65 \mathrm{~b}$ & 7.98 \\
\hline Shallow Tillage & 7.67 & 7.93 & 8.39 & $8.00 \mathrm{~b}$ & 8.68 \\
\hline Zero Tillage & 6.87 & 7.02 & 7.01 & $6.97 \mathrm{a}$ & 7.58 \\
\hline Mean & $7.28 \mathrm{a}$ & $7.55 \mathrm{ab}$ & $7.78 \mathrm{~b}$ & 7.54 & 8.08 \\
\hline
\end{tabular}

Source: Smith et al., 2014

The right hand column shows the estimated winter wheat yields for controlled traffic systems with a traffic lane area of $15 \%$. The $10 \%$ Isd's for the main effects of tillage and traffic are both $0.35 \mathrm{t} / \mathrm{ha}$ and $0.61 \mathrm{t} / \mathrm{ha}$ for their interaction; traffic $p<0.07$; means not followed by the same letter are significantly different 


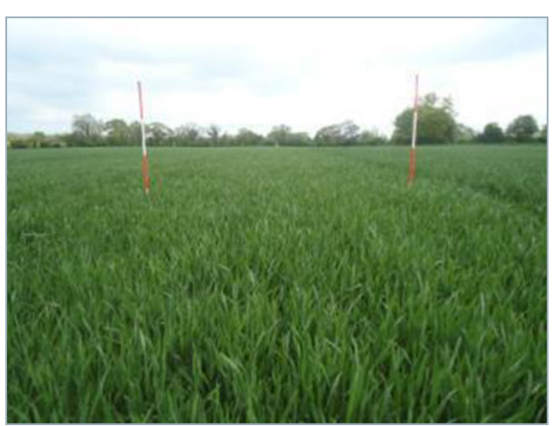

RTF deep tillage

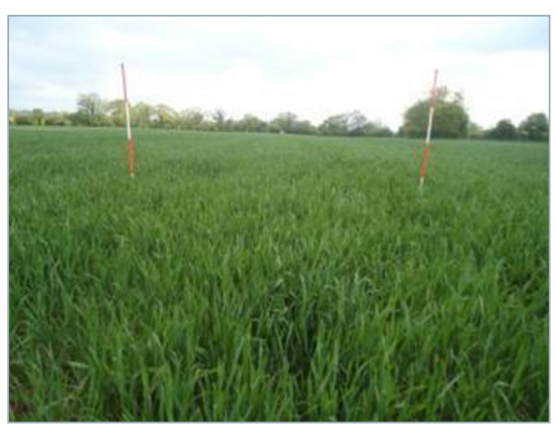

LPG deep tillage

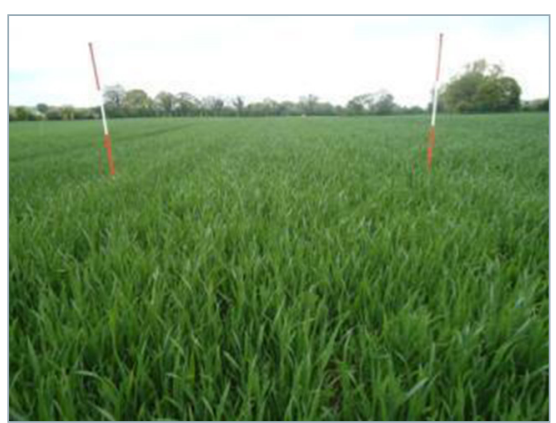

CTF deep tillage

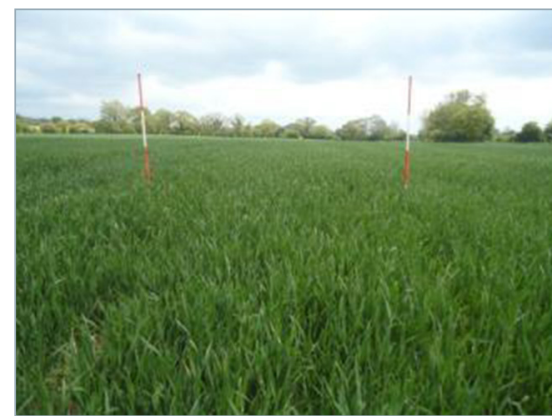

RTF shallow tillage

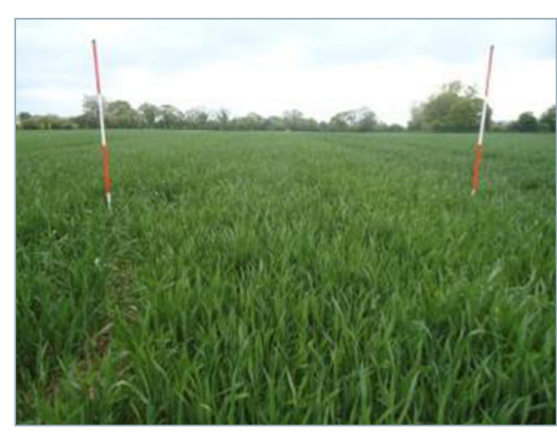

LPG shallow tillage

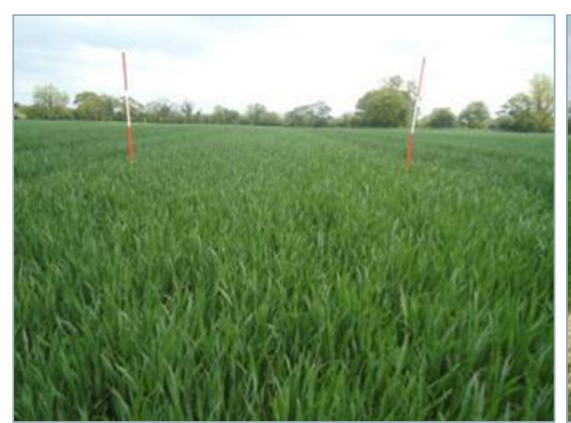

CTF shallow tillage

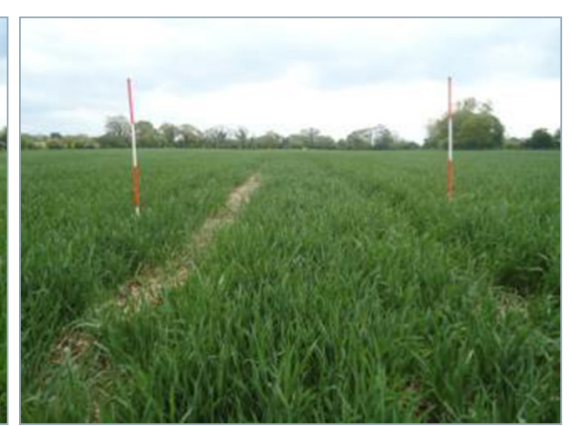

RTF zero tillage

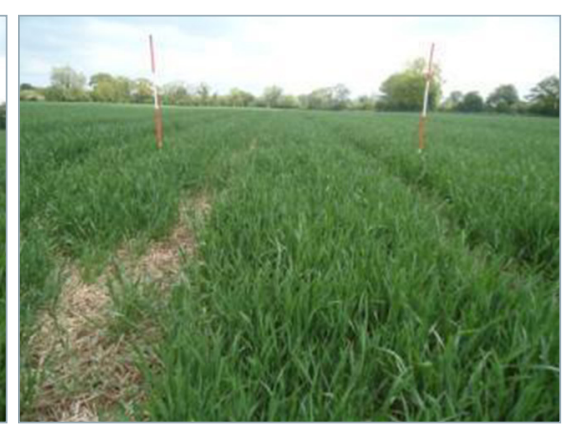

LPG zero tillage

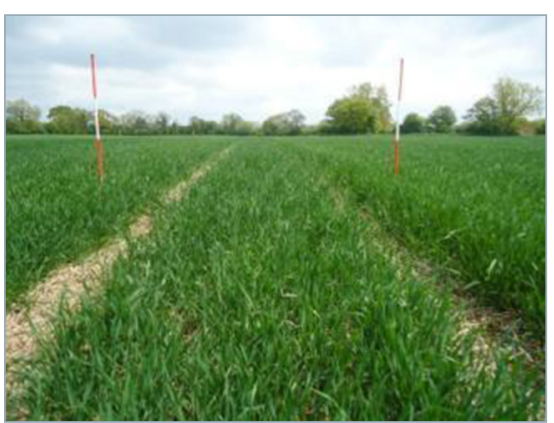

CTF zero tillage

Figure 8 Winter wheat condition on $29^{\text {th }}$ May 2013, showing poor crop growth in the wheel marks of all zero tillage plots Source: Smith et al., 2014

shallow tillage treatment shows a significant $(p<0.10) 9 \%$ (0.64 t/ha) increase. The adjusted estimated data show that reducing the trafficked area to $15 \%$ increases CTF/shallow tillage yield by $19 \%$ (1.39 t/ha) over the RTF/deep tillage treatment.

Table 4 Hand harvested winter wheat yield (t/ha) in 2013 in the traffic lanes and non-trafficked zones of the controlled traffic system plots

\begin{tabular}{|l|c|c|c|}
\hline & Traffic lane & Non-trafficked & Mean \\
\hline Deep Tillage & 7.69 & 8.97 & $8.33 a$ \\
\hline Shallow Tillage & 7.04 & 8.10 & $7.57 a$ \\
\hline Zero Tillage & 4.33 & 10.51 & $7.53 a$ \\
\hline Mean & $6.35 a$ & $9.19 b$ & 7.81 \\
\hline
\end{tabular}

Source: Smith et al 2014

The $10 \%$ Isd's for the main effects of tillage and traffic are $1.51 \mathrm{t} / \mathrm{ha}$ and $1.84 \mathrm{t} / \mathrm{ha}$ respectively and $2.61 \mathrm{t} / \mathrm{ha}$ for their interaction; means not followed by the same letter are significantly different
The apparent poor performance of the zero tillage treatments should be treated with caution at this stage for the following reasons:

1. The yield is often lower in early years of conversion to zero tillage and will usually increase with time as soil structure improves (Carter, 1994); (hand sampled yields (Table 4) would suggest that this is less of an issue in nontrafficked soil).

2. It is the poor yield in the traffic lanes that effected performance, as the yield in the non-trafficked zone of the zero tillage plots was estimated at $8.15 \mathrm{t} / \mathrm{ha}$ (with the hand harvested data showing a yield of $10.51 \mathrm{t} / \mathrm{ha}$ ).

3. Alternative "no-till" drills may have been better suited to the conditions that prevailed in the traffic lanes when establishing the crop in 2012 but were not available.

These results, although only based upon one year's data, show trends similar to those found in earlier research; they provide further confidence albeit at a $10 \%$ probability level that is logical and one on which farmers would be confident to make management decisions. 


\section{Implications for Further Work}

A number of important factors should be considered when undertaking work in this area. These are as follows:

1. Understand the underlying soil variation and attempt to remove heterogeneity from imperfect soil structure and drainage before experimental work starts. This also applies to farm practice, as the structure of the soil, especially sandy loams, may not naturally improve their structure from lower traffic impacts alone. Stobart and Morris (2011) found analogous results where sustained shallow tillage did not show improvements in soil structure compared to other systems. Further details on soil examination and alternative soil loosening techniques are given in Godwin and Spoor (2015).

2. Ensure a robust experimental design and adequate replication for field experiments. Whilst this applies to all field studies, it is often difficult to arrange with large-scale mechanization systems.

3. Field plots for this type of study are large and hence with adequate replication cover significant areas of the field, which in turn can lead to greater levels of soil

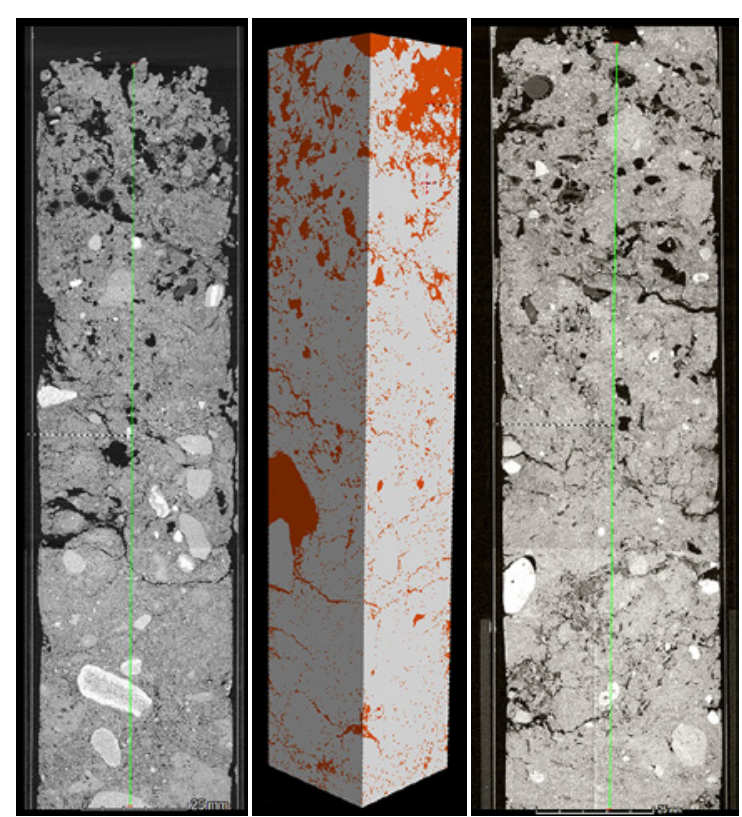

Zero tillage
Shallow tillage

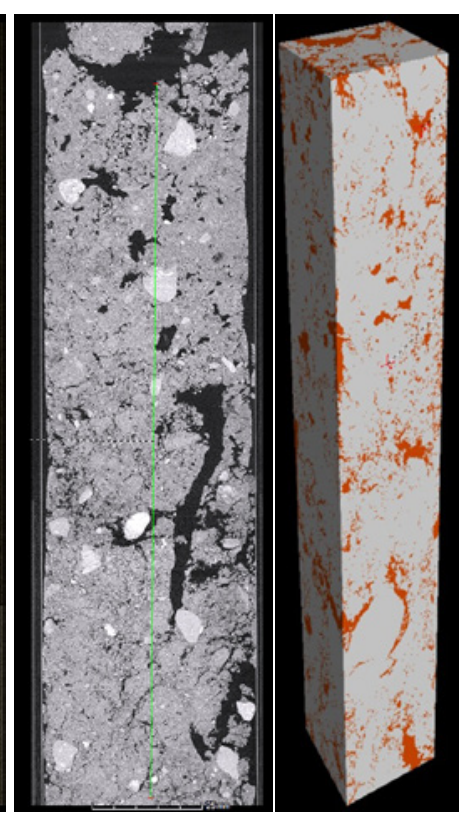

Deep tillage

Figure 9 Unpublished results of X-ray computer tomography for the non-trafficked area of the CTF Treatments

Source: Nottingham University \& Harper Adams University data

heterogeneity and greater variation in experimental data. There is a danger that overly rigorous statistical significance levels may well impede sensible adoption of improved soil management methods and is the reason why the $10 \%$ level has often been quoted in these results. Many practitioners would be happy to adopt improved management methods at this probability level.

In order to strengthen the case regarding the question of the significance levels, Table 5 shows a technique for combining all the probabilities of the

Table 5 An example of the results of combining probabilities from independent tests of significance, for five data sets using the methodology given in Sokal and Rohlf (1981)

\begin{tabular}{|c|c|c|}
\hline Site/Crop/Harvest Year & $P$ & $\ln P$ \\
\hline Morley/Winter Wheat/2008 & 0.07 & -2.65926 \\
\hline Colworth/Winter Wheat/2010 & 0.05 & -2.99573 \\
\hline Nitra/Winter Wheat/2011 & 0.05 & -2.99573 \\
\hline Nitra/Spring Barley/2012 & 0.15 & -1.89712 \\
\hline Nitra/Maize/2013 & 0.10 & -2.30259 \\
\hline Newport/Winter Wheat/2013 & 0.07 & -2.65926 \\
\hline$\Sigma \ln P$ & & -15.50969 \\
\hline$-2 \Sigma \ln P$ & & 31.01938 \\
\hline$\chi_{0.01}^{2}$ probability and 12 degrees of freedom & & 26.22 \\
\hline$\chi_{0.001}^{2}$ probability and 12 degrees of freedom & & 32.91 \\
\hline
\end{tabular}

series of separate significance tests for the different data sets to test the hypothesis using a method developed by Fisher (Sokal and Rohlf, 1981). This yields a probability between 0.01 and 0.001 for the data given, with the exception of the Chicksands data (Chamen, 2011), which was not significant, and shows that for the other studies there is sufficient evidence to reject the "null" hypothesis that "traffic management systems have no effect on crop yield".

4. Evaluate the soil conditions that provide optimal crop development such that they may be used to describe and target soil management practices, rather than just specifying a machinery management system.

The use of X-ray computer tomography as shown in Figure 9 is being investigated to assist in fully comprehending soil porosity and root development from alternative soil management systems.

5. Investigate the benefit of improved management of wheel traffic lanes especially with "No-till" systems particularly for crop establishment in wet soil conditions.

6. With the evidence that is building with respect to improved soil management we should continue 
to work with equipment manufactures to provide fully integrated CTF compatible mechanization systems.

\section{Conclusions}

The ultimate system for reducing the adverse effects of field traffic, namely controlled traffic farming, exhibits benefits in the form of improved crop yields, reduced energy inputs and improved soil infiltration characteristics. The above evidence shows that with sufficient ingenuity by farmers and their equipment suppliers in matching operating widths and wheel track gauges the appropriate aftercare should improve crop yield, and reduce energy consumption while improving infiltration rates and reducing runoff, erosion and flooding. These together will improve agronomic, economic and environmental sustainability. If issues of soil management in the wheel marks in wet soils can be overcome, then Zero-Till practices should be complimentary to improved traffic management. Whilst the crop yield improvements are not as high as CTF, there is evidence that low ground pressure systems for wheel loads up to a maximum of around $5 \mathrm{t}$ can offer farmers an alternative to controlled traffic.

\section{Acknowledgements}

Keith Chaney (formerly Harper Adams University) for agronomic advice; Sacha Mooney (Nottingham University) for the collaboration with the X-Ray Computer Tomography; Charles Marshall (formerly Cranfield University - Silsoe) and Peter Kettlewell (Harper Adams University) for statistical advice. The technical support staff of Harper Adams University for their help with the field work. Also the Douglas Bomford Trust, AGCO, Agrii, Michelin, Precision Decisions, Rea Valley Tractors, SOYL and Vaderstad for their sponsorship/assistance of/in the experimental work at Harper Adams University. To Bruce Ball, Lars Munkholm and $\mathrm{CABI}$ for permission to reproduce the short passage of text referred to.

\section{References}

CARTER, M. R. 1994. Conservation tillage in temperate agroecosytems. Lewis, Boca Raton.

CHAMEN, W. C. T. - VERMEULEN, G. D. - CAMPBELL, D. J. - SOMMER, C. 1992a. Reduction of traffic-induced soil compaction: a synthesis. In Soil \& Tillage Research, vol. 24, no. 4, pp. 303-318.

CHAMEN, W. C. T. - WATTS, C. W. - LEEDE, P. R. - LONGSTAFF, D. J. 1992b. Assessment of a wide span vehicle (gantry), and soil and crop responses to its use in a zero traffic regime. In Soil \& Tillage Research, vol. 24, no. 4, pp. 359-380.

CHAMEN, W. C. T. 2011. The effects of low and controlled traffic systems on soil physical properties, yields and the profitability of cereal crops on a range of soil types. PhD thesis. Cranfield University, Cranfield, Bedfordshire, UK.

CHYBA, J. 2012. The influence of traffic intensity and soil texture on soil water infiltration rate. MSc Thesis. Harper Adams University College, Newport, Shropshire, UK.

GALAMBOŠOVÁ, J. - RATAJ, V. - MACÁK, M. - ŽITŇÁK, M. NOZDROVICKÝ, L. 2010. Controlled traffic farming and minimum tillage: results of initial experiments and layout of a longterm experiment. In XVII th World Congress of the International Commission of Agricultural and Biosystems Engineering (CIGR).
Retrieved from: https://www.bioeng.ca/publications/meetings-ap ers?sobi2Task=sobi2Details\&sobi2ld $=494$

GALAMBOŠOVÁ, J. - MACÁK, M. - RATAJ, V. - GODWIN, R. J. ŽITŇÁK, M. - VITÁZKOVÁ, B. - ĎUĎÁK, J. - CHAMEN, W. C. T. 2014. Yield performance of controlled traffic farming permanent tramlines. Paper Number 142005820, ASABE Annual International Meeting 2014, ASABE, St. Joseph, Michigan, USA.

GODWIN, R. J. 2014. Potential of "No-till" Systems for Arable Farming. The Worshipful Company of Farmers. London.

GODWIN, R. J. - SPOOR, G. 2015. Choosing and evaluating soil improvements by subsoiling and compaction control. In Ball, B. C. - Munkholm, L. J. (eds). Visual Soil Evaluation: Realising Potential Crop Production with Minimum Environmental Impact. CABI, Wallingford, UK.

KRISTOF, K. - SMITH, E. K. - MISIEWICZ, P. A. - KROULIK, M. - WHITE, D. R. - GODWIN, R. J. 2012. Establishment of a long term experiment into tillage and traffic management. Part two: Evaluation of spatial heterogeneity for the design and layout of experimental sites. In International Conference of Agricultural Engineering, CIGRagENG2012, Valencia, 8-12 July, 2012.

KROULIK, M. - KUMHALA, F. - HULA, J. - HONZIK, I. 2009. The evaluation of agricultural machines field trafficking intensity for different soil tillage technologies. In Soil \& Tillage Research, vol. 105, no. 1, pp. 171-175.

KROULIK, M. - KVIZ, Z. - MASEK, J. - MISIEWICZ, P. A. 2012. Benefits of GPS agricultural guidance for sustainable agriculture. In Agrociencia, vol. 16, no. 3, pp. 107-116.

MICHELIN. Retrieved from: http://www.michelin-agricultural-tyres. co.uk/Michelin-Ultraflex-technologies

NEGI, S. C. - MCKYES, E. - RAGHAVAN, G. S. V. - TAYLOR, F. 1981. Relationships of field traffic and tillage to corn yields and soil properties. In Journal of Terramechanics, vol. 80, no. 2, pp. 81-90.

NFU. 2013. Retrieved from: http://www.fwi.co.uk/arable/ wheat-yields

SOEHNE, W. 1958. Fundamentals of pressure distribution and soil compaction under tractor tires. In Agricultural Engineering, vol. 39, pp. 276-281, 290.

SOKAL, R. R. - ROHLF, F. J. 1981. Biometry. The principles and practices of statistics in biological research. $2^{\text {nd }}$ edition, W. H. Freeman and Company, San Francisco.

SMITH, E. K. - MISIEWICZ, P. A. - WHITE, D. R. - CHANEY, K. GODWIN, R. J. 2013. An investigation into the effect of traffic and tillage on soil properties and crop yields. ASABE Paper No 1597846, St. Joseph, Michigan, USA.

SMITH, E. K. - MISIEWICZ, P. A. - GIRARDELLO, V. - ARSLAN, S. CHANEY, K. - WHITE, D. R. - GODWIN, R. J. 2014. Effects of traffic and tillage on crop yield (Winter Wheat Triticum aestivum) and the physical properties of a sandy loam soil. ASABE Paper No 1912652, St. Joseph, Michigan, USA.

STOBART, R. - MORRIS N. L. 2011. Sustainability Trial in Arable Rotations (STAR project): a long term farming systems study looking at rotation and cultivation practice. In Aspects of Applied Biology, vol. 113 (Making Crop Rotations Fit for the Future).

TULLBERG, J. N. - YULE, D. F. - MCGARRY, D. 2007. Controlled traffic farming - From research to adoption in Australia. In Soil and Tillage Research, vol. 97, no. 2, pp. 272-281. 